\title{
pro.posıções
}

$e$-ISSN 1980-6248

http://dx.doi.org/10.1590/1980-6248-2016-0167

ARTIGOS

\section{Quem são os idiotas, afinal?}

\section{Who are the idiots, after all?}

Hamilton Viana Chaves (i)

Osterne Nonato Maia Filho (ii)

Maria Susana Vasconcelos Jimenez (iii)

Betânea Moreira de Moraes (iv)

(i) Universidade de Fortaleza, Fortaleza, CE, Brasil. http://orcid.org/0000-0003-4959-8173. hamilton@unifor.br

(ii) Universidade Estadual do Ceará, Fortaleza, CE, Brasil. osterne_filho@uol.com.br

(iii) Universidade Federal do Ceará, Fortaleza, CE, Brasil.susana_jimenez@uol.com.br

(iv) Universidade Estadual do Ceará, Fortaleza, CE, Brasil. betaneamoraes@gmail.com

Resumo: O participante da polis, no sentido grego, era aquele que deliberava sobre a vida coletiva. À condição de manifestado desinteresse pelo Estado, os gregos denominavam Ï̊ıoৎ (idiótes), de onde deriva o termo "idiota". É na tensão entre gnosiologia e ontologia que o idiota será localizado ao longo de todo o pensamento moderno. $\mathrm{Na}$ atual conjuntura de sociabilidade, indaga-se: quem são os idiotas, afinal? Na condição de ensaio teórico, esta discussão pretende, a partir de uma perspectiva crítica, apontar indícios para tal condição: afirma-se que os idiotas comporiam o que se denomina maioria. Ainda mais, o estudo leva a crer que um dos desafios centrais à existência humana, desde as circunstâncias de sociabilidade da cidadania grega até as diversas transições e representações da sociedade capitalista, reside no complexo de relações indivíduo-gênero.

Palavras-chave: idiota, teoria crítica, ontologia, formação humana 


\section{pro.posições}

$e$-ISSN 1980-6248

http://dx.doi.org/10.1590/1980-6248-2016-0167

Abstract: The participant of the polis, in its Greek meaning, was the one who deliberated over the collective life. The condition of manifested disinterest toward the state was denominated by the Greek as Ïठtos (1diótes), from which the term "idiot" derives. In the tension between gnosiology and ontology, the idiot will be located throughout the modern thought. In the current conjuncture of sociability, the following question may be asked: who are the idiots, after all? Under the condition of a theoretical essay, this discussion aims, from a critical perspective, to show signs for such a condition. In this direction, it is pointed out that today the idiots would compose what is called the majority. Moreover, the study leads to the belief that, from the circumstances of sociability in the context of Greek. citizenship until the various transitions and representations of capitalist society, one of the central challenges to buman existence lies in the complex of individual-gender relationships.

Keywords: idiot, critical theory, ontology, buman formation

\section{Introdução}

O participante da polis, no sentido grego, era aquele que deliberava sobre a vida coletiva. Era também responsável por juízos produzidos com fins de administrar a cidade, o que incluía decisões sobre o público e o privado. À condição de manifestado desinteresse pelo Estado, os gregos denominavam Ï̊ıৎ (idiotes), de onde deriva o termo “idiota”, em língua portuguesa. O aparte da vida política, sobretudo quando envolvia situações consultivas e deliberativas, representava uma ameaça ao sentido de democracia da tradição grega - nada mais contraditório à própria formação cultural e política das cidades-estados da Grécia antiga.

Essa contradição põe em manifesto discrepâncias relativas à ambiência fértil com que a sofia se deparou. Fato marcante é que, desde os pré-socráticos, os sujeitos de conhecimento estavam dispostos a fazer perguntas e averiguá-las. Isso se dava tanto de uma perspectiva mais reflexiva sobre as condições do próprio conhecimento (gnose) ou do ser em sua existência (ontos), como em discussões mais relativas à experimentação subjetiva e pragmática cotidiana, tais como aquelas encontradas no estoicismo ou no hedonismo. Em tese, qualquer cidadão grego, embora tal possibilidade não fosse extensível aos escravos e às mulheres, poderia ir até a ágora e expor suas ideias, influenciando, assim, o destino da polis da qual era parte inseparável. Portanto, nesse cenário o idiota é entendido como um sujeito estranho ao mundo grego. 


\section{pro.posições \\ $e$-ISSN 1980-6248}

http://dx.doi.org/10.1590/1980-6248-2016-0167

É fato que o percurso delineado a partir da cultura grega e que se adentrou na modernidade imputou ao idiota outras perspectivas. Garcia-Roza (2005) assinala a emergência do racionalismo de Descartes como o momento que aponta e resgata não só o sujeito moderno, antropocêntrico e racional, mas também o seu contraponto, o sujeito que confunde verdade com erro, realidade com imaginação, o louco ou o idiota. Tal perspectiva filosófica emergente se tornaria, logo depois, em prática e intervenção médicas.

Foi notadamente a tradição médica, em conformidade com Philippe Pinel (1745-1826), Jean-Marc-Gaspard Itard (1774-1838) e Edouard Séguin (1812-1880), que outorgou ao idiota uma outra condição, a médico-higienista, na qual o ser idiota estaria mais relacionado ao uso e à produção do conhecimento. Essa conjunção apontada como existencial teve consequências diretas na vida cotidiana, pois, embora a referência ao ser idiota proviesse de sua condição de elaboração de conhecimento, sua marca subjetiva, o ser idiota, era o delimitador para sua participação na sociedade, o que viria a ameaçar sua própria existência (Van Drenth, 2007). Seria mais prudente segregar o idiota em instituições hospitalares e asilares, o que possibilitaria protegê-lo dos infortúnios que pudesse vir a sofrer por parte dos sóbrios civis, ao mesmo tempo em que se preservava a esfera de racionalidade própria da sociedade.

Foucault (2014), em sua famosa obra História da loucura, particularmente no capítulo denominado "Os insensatos", resgata, numa espécie de arqueologia e genealogia, o paradoxo que fez confluir, no mundo ocidental moderno, uma condição social a um quadro patológico. Se, num primeiro momento, a loucura ou insensatez é julgada pela incapacidade cognitiva de distinguir verdade e erro em razão de uma falha constitutiva, visto que ser racional é inerente ao homem, como pensava Descartes, o avanço da investigação médica levou a questão a uma confluência mais radical. Tal indiscriminação produz o excesso, a falta de controle dos pensamentos, das condutas e das paixões, a insensatez que aproxima perigosamente a loucura de um comportamento moral e socialmente indesejável. Essa inadequação não era, de fato, casual, pois a motivação que justificou a segregação dos loucos, o seu asilamento, foi estendida a outros párias sociais: devassos, feiticeiros, velhos, inválidos, deficientes. Eis a tese de Foucault: todos aqueles que não servem para o trabalho, na florescente sociedade burguesa, são retirados do convívio com o outro, por não terem valor social. Não só cometem excessos - são um excesso. Cometem excessos, porque lhes falta algo: razão, sensatez, bom senso, equilíbrio ou normalidade. 


\section{pro.posıções}

$e$-ISSN 1980-6248

http://dx.doi.org/10.1590/1980-6248-2016-0167

Essa segregação permitiu uma aproximação mais direta da situação do idiota, ao passo que foi possível delimitar e compreender o ser não idiota sob o viés da ciência: o ser de razão sensata. Essa bifurcação foi determinante para a proliferação, afirma Zenderland (1998), de uma variedade de termos que viriam a se aplicar ao idiota e que se relacionariam com a graduação de seu afastamento da razão, da sensatez e do comedimento. Essa categorização correspondia a uma escala linear e analógica que variava desde imbecis (sujeitos com ligeira deficiência), passando por débeis mentais, até atingir o outro extremo, representado pelo ser idiota. O que se afigurava nessa taxonomia era o nível de complexidade, ou melhor, a incapacidade que o idiota possuía de realizar juízos que envolvessem condições mínimas decisórias com respeito não só a juízos, raciocínios, afetos e comportamentos em relação à vida em sociedade, mas também às suas próprias vidas.

A tradição médica também forneceu subsídios para analisar o arranjo e a expressão da razão no formato de inteligência privilegiada, compreendida como o extremo oposto ao comportamento idiota. Foi Francis Galton (1822-1911), a partir do legado de Charles Darwin (1809-1882), que propôs uma teoria da inteligência humana baseada nas condições mínimas de sensorialidade do sujeito. Para Galton, quanto mais precisa fosse a capacidade de discriminação dos estímulos sensoriais, mais inteligente seria o sujeito. Ainda como herança da evolução das espécies, Galton sugeriu que essa capacidade de discriminação sensorial era espólio genético, fato que o levou a propor uma teoria eugênica, a fim de preservar "as melhores frações" da existência humana, no que diz respeito ao aspecto inteligência (Almeida, 1988).

De fato, na base do pensamento de Galton, embora ele não fosse médico de formação, está o dilema que organizou o pensamento científico moderno: a base predominantemente orgânica ou social da natureza humana. Sua opção pelo modelo hereditário facilitaria as coisas, visto que ser idiota ou não inteligente não mais redundaria em uma culpa pessoal ou social, mas faria apenas parte das "engrenagens" da natureza, com seus feitos maravilhosos ou suas falhas, pois, nesse caso, o sujeito nasceu para ser inteligente ou, infelizmente, com um defeito de "fábrica”. Parece um raciocínio lógico e inteligente e, ao mesmo tempo, idiota, pois como seria possível ignorar a importância da história, da cultura, ou seja, do ser social, na formação humana? Essa perspectiva não só confirmaria a tese, mas poderia levar a excessos: a irracionalidade em nome da razão. 


\section{pro.posıções}

$e$-ISSN 1980-6248

http://dx.doi.org/10.1590/1980-6248-2016-0167

Tal prerrogativa pressupunha não apenas asilar os incapazes idiotas, mas também cuidar da perpetuação de sujeitos que seriam "mais interessantes" à sociedade, no que diz respeito à transmissão do legado biológico da inteligência. Mais tarde, com a recapitulação do movimento higienista, esse apartheid ampliou-se para além das condições de inteligência, abrangendo, inclusive, aspectos relativos à moral, à sexualidade e à raça.

Essa extrapolação seria responsável, segundo o estatuto da razão, por movimentos como o nazifascismo na Europa ou a segregação racial nos Estados Unidos. Nesse último caso, foi somente com um levante promovido pelo Movimento dos Direitos Civis, a partir de meados da década de 1950, que se começaram a esboçar condições diferentes para os negros norte-americanos, embora, nos dias atuais, ainda existam expressões indiscutíveis de segregação racial naquele país.

As incongruências ampliadas pelo confronto da razão com os fatos históricos, como a Segunda Grande Guerra Mundial, o tecnopólio segregacionista norte-americano (Postman, 1994), entre outras manifestações, permitiram difusas análises sobre contradições presentes na sociedade moderna. Uma primeira investida identificada é aquela que partiu de Adorno (1995), ao escrever com perplexidade sobre as agruras do nazismo na Alemanha e a política de dizimação de idiotas: idiotas políticos, raças idiotas, idiotas sexuais e idiotas no sentido médico do termo, etc. Como se daria a organização da educação após Auschwitz? - indagava Adorno. Como repousar as consciências, se os educadores não foram aptos a identificar com precisão sujeitos capazes de realizar tamanha atrocidade? Caso os educadores tivessem identificado tal realidade, teriam poder político para ser ouvidos ou agir?

Talvez uma das possíveis respostas a tais inquietações pudesse partir de uma análise de orientação pós-crítica, na afronta direta à modernidade. É nessa senda que Bárcena (2015) trata dessa temática a partir do "olhar da diferença". O idiota seria o diferente e, como tal, pertencente a uma minoria que facilmente poderia sucumbir a leis segregacionistas e higienistas e a códigos que possibilitariam, de forma justificada e legal, seu extermínio. Amiúde, o curso dessa última análise, sob o viés dito pós-crítico, se aplicaria à localização de minorias que seriam negligenciadas por uma ampla maioria, sobretudo no que diz respeito ao acesso a direitos humanos e a garantias mínimas de sobrevivência. 


\section{pro.posıções}

http://dx.doi.org/10.1590/1980-6248-2016-0167

$e$-ISSN 1980-6248

Entretanto, o esteio dessa perspectiva teórica apresentar-se-ia com alguns limites seminais: o primeiro corresponderia exatamente ao fato de não realizar uma análise mais adensada das bases materiais que desencadeiam tal processo, ou seja, que conformam os diferentes modos de organização psíquica e social. Dizendo de outro modo, careceriam de uma investigação mais meticulosa as leis que contradizem a história que posicionou o idiota nos diversos patamares que ele ocupou, desde seu "nascimento", no bojo da sociedade grega, até seu papel na sociedade mercantil capitalista. O segundo problema, que, de certa forma, decorre desse primeiro, diz respeito ao fato de que se vislumbrou, sobretudo a partir de meados do século XX, uma viragem na relação entre minoria e maioria, no que diz respeito ao "ser social idiota".

Trata-se de argumentos complexos, cuja trama, obviamente, seria impossível esgotar no escopo deste artigo, mas que não deixa de ensejar uma contribuição ao problema que a questão do idiota impõe à nossa sociabilidade hodierna. Nesse sentido, a análise da presente reflexão se pauta numa perspectiva claramente ensaística (Adorno, 1994), de natureza mais teórica e bibliográfica, visando a uma leitura mais descritiva e exploratória da questão do que a uma pretensa e inequívoca resposta explicativa ao dilema acerca da forma como a aparente idiotização do ser social tem se configurado na atual história do gênero humano.

Nessa linha de leitura do mundo, pretendemos pautar-nos numa perspectiva teórica e metodológica de análise calcada numa visão dialética, crítica, contextualizada e sistêmica da realidade, tomando como parâmetro básico de interpretação o homem em suas relações materiais com a natureza e com o outro; ou, em outros termos, o ser humano genérico, decorrente de sua experiência material e relacional com o outro na sua vida social.

\section{O idiota na contradição da história}

A meticulosa análise que Karl Marx (1818-1883) realizou da evolução das sociedades humanas teve o mérito de perscrutar o já realizado, o passado; e apontar possíveis destinos que a humanidade poderia ocupar, o futuro. O empenho de Marx residiu em identificar as leis que organizariam as mudanças da sociedade, sobretudo naquilo que ele denominou modos e relações de produção da existência humana, o que incluiria os sóbrios, os alienados, os opressores, os idiotas, etc. A magnitude de seu legado, no entanto, não reside exatamente na 


\section{pro.posıções}

$e$-ISSN 1980-6248

http://dx.doi.org/10.1590/1980-6248-2016-0167

originalidade da teoria e do método do materialismo histórico-dialético, como teoria e método que elucidaram a contradição e a luta de classes como motor da história humana; mas, sobremaneira, nos posicionamos do lado dos estudiosos que entendem que o caminho mais adequado para o resgate do caráter revolucionário do marxismo implica em apreender o legado de Marx como uma ontologia do ser social (o ser humano é um ser de relações com o outro social), em seus diversos modos de existência a partir de atributos da razão ou da "desrazão”. Em outras palavras, Marx não teria só revelado os fundamentos determinantes da sociabilidade capitalista e de sua superação, mas teria, sim, apontado o trabalho e as relações sociais que ele implica como ato gênese do ser social. Marx apreende e desvela os princípios gerais para compreender corretamente não apenas a condição humana em sua radical historicidade, mas também o que ela é e o que pode vir a ser, sobretudo a partir do cenário das contradições apresentadas pela racionalidade moderna.

Com efeito, quando, em sua obra madura, Gyorgy Lukács (2010) assume a tarefa de firmar a natureza ontológica do marxismo, resgatando a obra marxiana do terreno pantanoso das deturpações de cunho reformista, determinista, gnosiológico e dogmático historicamente arrogado a essa obra, o filósofo húngaro deixa evidente que Marx teria, ao fim e ao cabo, edificado uma teoria do gênero humano, o que implicaria no tratamento das complexas e contraditórias relações entre individualidade e generidade. Sempre fiel a Marx, Lukács reitera como tese central da sua Ontologia do Ser Social, o processo de trabalho como práxis primeira e modelo de toda práxis social.

Para Lukács (2010), “a práxis, como base do ser do homem, e de todos os momentos de seu ser, produz necessariamente [a] superação do mutismo do gênero, como base do seu autodevir já na fase mais primordial" (p. 54), tornando-se, progressivamente, "meio universal de domínio do homem sobre seu ambiente, instrumento adequado daquilo que distingue o trabalho, como adaptação ativa do homem ao seu ambiente, de qualquer adaptação préhumana" (p. 57).

O desenvolvimento das forças produtivas e das relações sociais de produção, por um lado, e a elevação das capacidades humanas, por outro lado, - alavancados pela natureza do trabalho de imprimir o novo, incessantemente e de forma cada vez mais complexa: novas necessidades e possibilidades materiais e humanas, novas intencionalidades e percepções da causalidade natural em conjunção com os desdobramentos e as rupturas que as relações de 


\section{pro.posıções}

$e$-ISSN 1980-6248

http://dx.doi.org/10.1590/1980-6248-2016-0167

produção nas sociedades de classes experimentariam -, determinariam os modos de produção tanto material quanto espiritual do ser social. Portanto, os modos de produção teriam a ver com a natureza do trabalho e com os meios adequados à produção dos bens necessários à sobrevivência e à vida humana e com as relações sociais ali implicadas. Ressalte-se que a primazia em Marx não reside exatamente no conhecimento sobre a especificidade técnica na utilização de certas ferramentas e instrumentos de trabalho, embora isso seja condição necessária à evolução da espécie humana, mas está na condição social que garante tal conhecimento.

A teoria desenvolvida por Marx vai além, alçando à condição de centralidade do processo emancipatório a classe trabalhadora, uma vez que essa seria o sujeito das irrupções revolucionárias, consequência das lutas de classe oriundas da relação de exploração entre capital e trabalho. Belo paradoxo, o trabalhador alienado e "idiota" é alçado ao protagonismo da transformação social. Na prática, porém, da vida dominada pelo paradigma burguês atual, tal ideia é uma idiotice, a ponto de se atribuir a essa interpretação da realidade, através de argumentos "lógicos" dos ideólogos de plantão, uma total perda de realidade.

Esses fatos ensejariam algumas questões: afinal, quem são os idiotas e para que servem? De que forma tirar proveito de sua condição, para além da segregação? De fato, a consideração do sujeito como dimensão fundamental na evolução das sociedades de classe permitiria que sua análise se estendesse às suas possíveis nuanças ontológicas. Faz sentido, portanto, o exame mais pormenorizado do ser idiota na sua relação com a lógica produtiva, especialmente no modo de produção capitalista.

O posicionamento do ser idiota no atual modo de produção, o capitalista, permite sua localização em, pelo menos, dois nichos das forças produtivas. O primeiro nicho que o idiota contemporâneo pode ocupar mais se aproxima da clássica interpretação que Marx faz da ideia de estranhamento como uma primeira etapa daquilo que se configura como a concepção da alienação social em sua perspectiva sociológica. $\mathrm{Na}$ relação humana inaugural, a identificação com um outro (estranho a mim, alien) é fundamental - primeiro como um igual, cópia, imitação; depois como outro, mesmo, a princípio próximo e estranho a mim, realidade ao mesmo tempo ontológica e gnosiológica. Como destaca Wallon (2008), a criança não vai ao mundo senão através do outro: ato que a princípio é pouco adaptativo no mundo animal e se 


\section{pro.posıções \\ $e$-ISSN 1980-6248}

http://dx.doi.org/10.1590/1980-6248-2016-0167

torna a base do gênero humano. Alienar-se ao outro, ao estranho, é um ato fundante de futuro autorreconhecimento, pois a diferença vem da igualdade desigual.

Marx (1993) esclarece, contra toda tradição filosófica idealista e materialista vulgar, que o meio pelo qual a alienação e o estranhamento ocorrem é "prático" (p. 168), isto é, sua base é material, objetiva e se inaugurou lá no ato do trabalho alienado. O trabalho coletivo implica na condição básica de alienação, numa certa medida, ao trabalho do outro do qual dependo e do qual ele depende. Mas tal realidade só se configura como uma alienação propriamente dita quando um sujeito que não trabalha diretamente sobre o real, o aparente "ser não idiota", se apropria indevidamente do trabalho alheio e que, portanto, não lhe pertence, enquanto o sujeito que trabalha, o aparente "ser idiota", não se apropria nem do produto, nem do ato processual de seu próprio trabalho. Marx adverte, nesse sentido, que somente pelo processo em que a consciência reflete a realidade é que a alienação toma uma dimensão subjetiva e vai se exteriorizar como ato/atitude, na relação do sujeito com a natureza e com o gênero humano, seja através da relação alienada com os outros indivíduos, seja consigo mesmo.

O trabalho alienado coloca-se, assim, como o fundamento ontogenético das múltiplas e complexas formas de manifestação da alienação que atravessam a práxis social, impondo severos limites ao desenvolvimento da vida genérica dos indivíduos. Com efeito, situando a escravidão como forma original de desigualdade, quando, a rigor, "o estranhamento entra na vida", Lukács (2010, p. 246) vai adiante para reiterar que, também "para o possuidor de escravos, as exigências necessárias do ser social... destroem as relações autênticas com a própria generidade” (p. 246); portanto, sua paradoxal condição de idiota se personifica. E, então, ultima: "assim transcorre toda a história das sociedades de classe” (p. 246). Marx e, após ele, Lukács, todavia, entendem os limites engendrados pela sociedade de classes à plena relação entre o indivíduo e o gênero humano como elementos contraditórios de caráter histórico; passíveis, portanto, de superação revolucionária. De forma alguma, em outras palavras, o complexo da alienação se configura em mediação inerente à natureza humana, embora os níveis de degradação da essência humana sejam intensificados com o desenvolvimento do sistema capitalista e, ainda de forma mais perversa, devemos acrescentar, no quadro da barbárie contemporânea.

De fato, na teoria de Marx $(1989,1993)$, que vai do conceito de alienação, em seus escritos de juventude, ao conceito de fetichismo, em sua obra de maturidade, é possível traçar 


\section{pro.posıções}

$e$-ISSN 1980-6248

http://dx.doi.org/10.1590/1980-6248-2016-0167

uma linha de continuidade na descontinuidade, conferindo-se, mais ainda, um caráter dialeticamente unitário à sua obra. Não obstante reconheça a relevância dos Manuscritos econômico-filosóficos de 1844 para o entendimento radical da teoria marxiana da alienação, Lukács (2010) observa que a problemática da alienação se faz presente na totalidade da obra de Marx, aí incluindo, obviamente, O capital. Lukács (2013) não hesita em refutar qualquer contraposição entre um jovem Marx "filósofo" e um Marx "econômico”, da maturidade, da maturidade, asseverando que

em Marx, a continuidade da colocação de problemas e da metodologia não foi sequer interrompida. Ao contrário, a possibilidade metodológica da correta fundamentação econômica de cada fenômeno social, de cada desenvolvimento social, é impensável sem [as] conquistas ontológicas do jovem Marx. (p. 152)

Nessa mesma linha de apreensão do caráter dialeticamente unitário da obra de Marx, Mészáros (2009) mostra-se convicto de que "os Manuscritos de 1844 anteciparam adequadamente o Marx posterior, apresentando numa unidade sintética a problemática de uma reavaliação ampla, centrada na práxis, de todas as facetas da experiência humana” (p. 24).

De todo modo, a teoria marxista da alienação, no limite, relaciona-se com o pensamento de que a ideologia, que pode significar uma alienação no nível da representação e da identificação, mascara o real e suas determinações onto-históricas. Assim, o não se dar conta de seu ofuscamento responderia a uma jornada de manter o sujeito afastado da compreensão das condições mais reais de exploração, como aquelas presentes na produção e na realização da mais-valia.

O caso particular do idiota, dessa vez como pertencente a uma maioria, residiria no fato de que ele reagiria aos ensejos das tendências mobilizadoras do social, sem dar-se conta da capilaridade extensiva e de sua capacidade de manutenção do status quo. Quando o capital se transforma, ele o faz para resguardar o contexto de exploração, o controle do desenvolvimento das forças produtivas e para inibir as possíveis consequências da classe (parte) que almejaria a emancipação humana.

O segundo nicho que o idiota pode ocupar localiza-se nas formas mais sutis e não menos perigosas de manipulação social cuja força coercitiva não estaria dirigida pela 


\section{pro.posıções}

$e$-ISSN 1980-6248

http://dx.doi.org/10.1590/1980-6248-2016-0167

negatividade. A estratégia de sedução encontrada pelo capital relaciona-se com a representação do valor simbólico da mercadoria no formato de fetiche.

Essa segunda forma de representação redundaria, talvez, no modelo mais assertivo de estratégia de controle, cuja solução não estaria no campo da tentativa de mascarar o real. Nessa situação, o real seria apresentado e acompanhado da sedução da mercadoria, uma vez que tudo é mercantilizável: relações sociais, relações amorosas, relações sexuais, relações raciais, etc.

O ensejo desferido nessa última representação está exatamente no valor simbólico de representação dos bens sociais, das marcas, dos produtos, dos símbolos da indústria cultural, etc. (Chaves \& Maia Filho, 2016). Assim sendo, o avanço tecnológico dos últimos 50 anos e as anunciadas conquistas do universo tecnológico e cultural nos espaços amplos da sociabilidade, em hipótese alguma foram capazes de garantir que tais evoluções viessem acompanhadas do progresso e do crescimento humano, no horizonte da constituição de uma generidade para si. Portanto, a essa segunda representação de idiota não se pode imputar um caráter simplista e meramente adjetivado de alienação. Na verdade, existiria uma suposta consciência, ou melhor, uma ciência dos possíveis destinos da humanidade e, a despeito disso, qualquer transição de consciência (entre ingênua, mítica, iluminada, etc.) seria insuficiente para germinar a emancipação, se não vier acompanhada necessariamente da superação do trabalho alienado e das relações humano-sociais que daí resultam.

Há que se considerar que essas duas formas de representação do idiota no cotejo com o contexto do modo de produção capitalista provocaram densas mudanças no curso da humanidade, de tal modo que sua representação não estaria configurada por minoria de alienados e, muito menos, minorias que restam seduzidas ao fetiche da mercadoria. O desvelar dessa situação põe em manifesto que há, sim, uma maioria de toda sorte de sujeitos que vai desde aqueles mais imediatamente atrelados ao processo de produção da mais-valia, até intelectuais das mais diversas áreas das ciências, o que incluiria os intelectuais e, por que não dizer, os idiotas de ofício, acenando ao "idiotismo do ofício", termo utilizado por Marx (1985, p. 134) na obra $A$ miséria da Filosofia. 


\section{pro.posições}

$e$-ISSN 1980-6248

http://dx.doi.org/10.1590/1980-6248-2016-0167

\section{O idiota como maioria}

Chun (2009) relata que a entrada da televisão no Japão, ainda no início da década de 1950, foi acompanhada da exploração e da exposição da cultura japonesa. Adversa às formas ocidentais de representação imagética, a cultura japonesa se viu imiscuída com os valores ocidentais dos espetáculos televisivos. A cobertura do casamento real, em 1959, os protestos contra o Tratado Nipo-Americano de Segurança, em 1960, e os Jogos Olímpicos de 1964, serviram para reforçar a identidade japonesa. Entretanto, a ameaça se fazia quando produtos da cultura televisiva norte-americana, que passaram a ser importados para o Japão, arrebatavam toda uma massa de telespectadores.

Não parece fortuito que a análise desse embate da cultura japonesa com a cultura norte-americana tenha merecido apreciação mais aprofundada por parte de Jayson Makoto Chun. Sua interpretação faz parte de uma constatação da ampliação ou da inversão da lógica que enquadraria a minoria dos idiotas. O século XIX os representou como parcelas espúrias da sociedade que deveriam ser asiladas, conforme o estatuto das ciências médicas e modernas. O século XX recrudesceu essa lógica de minoria, não sob o viés da segregação, mas seguindo a ótica da diferença, na perspectiva pós-crítica de análise (Bárcena, 2015). O mais estranho: para resgatar as diferenças, em nome da igualdade entre as pessoas, mas sob o risco de suprimi-la, se tais diferenças são naturalizadas ao extremo, pois aí não há mais igualdade.

A lição de literatos, como Fiódor Dostoiévski (2008) e Nelson Rodrigues (1993), na esteira da análise crítica permitida por Marx, Lukács, Freud e tantos outros, possibilitaria uma melhor compreensão do fenômeno da inversão da lógica de minoria versus maioria dos idiotas. Dostoiévski já prenunciava, no final do século XIX, o que estaria por vir. Em seu romance $O$ idiota, o autor explora o personagem Míchkin, que apresentava ares de um idiota, para a sociedade russa de sua época. O que se percebe, ao longo da proposta do romance, é um sujeito que parte de um estereótipo de idiota - inclusive assim autodeclarado -, mas que exibe maestria e sinceridade na análise das situações cotidianas. Por vezes, apresenta-se como um ingênuo diante da sociedade reduzida a valores materiais da Rússia do final do século XIX; em outras tantas, mostra sabedoria, ao analisar as situações mais corriqueiras relativas a paixões, a desejos, a sorte e a destinos. 


\section{pro.posıções \\ $e$-ISSN 1980-6248}

http://dx.doi.org/10.1590/1980-6248-2016-0167

Ao observar o panorama de sua época, Nelson Rodrigues, quase cem anos após o empenho literário de Dostoiévski, teve a sensibilidade sarcástica de perceber os transeuntes da vida cotidiana, consagrada em obras como $O$ óbvio ululante. Sua análise recai sobre expressões de diversos idiotas que tentariam ocultar fatos tidos como degradantes de uma moralidade corrompida, para se manter indolentes e próximos a uma temperança casta.

Os fatos, obras de ficção, narrados por Dostoiévski e Nelson Rodrigues provocam incessantes espasmos na sociedade da razão, ao desvelar o oculto. Isso se dá quando um ponto de inflexão mostra a viragem entre uma suposta minoria - Míchkin ou os infelizes traídos, presentes nas crônicas de Nelson Rodrigues - e a maioria que assistiria às suas representações. Por caminhos diferentes, Dostoiévski e Nelson Rodrigues traçam os destinos na díade "astuto" e idiota.

No caso de Dostoiévski, o primevo idiota, Míchkin, mostra que, se assim o classificam, isso seria oriundo de interpretações médicas, haja vista que sua "mente fraca" seria decorrente de suas constantes crises de epilepsia. Mas a trama diária das relações humanas mostrará que ele não se presta a tal imperativo, uma vez que os diversos idiotas seriam aqueles que facilmente sucumbem à ganância e à depreciação do gênero humano - caso de inúmeros personagens que aparecem no romance.

O trajeto percorrido por Nelson Rodrigues é aquele de indicar o potencial personagem (minoria), passível escárnio por parte da sociedade dita sóbria (maioria), que, a todo custo, tenta ocultar suas paixões mazeladas, seus excessos; e os reprime, como diria Freud. A tensão recairia sobre os desafortunados, uma vez que seu esforço se comparava ao Sísifo: uma ação cansativa e irrealizável. A viragem ocorre quando os idiotas têm insights, como aqueles que regiam as ações dos símios de Köhler, a respeito de suas realidades circundantes. Os idiotas começaram e se reconhecer, a se identificar como coletividade. Em toda parte havia idiotas. Sua expansão dava-se conforme o preceito do "crescei e multiplicai-vos". Esse reconhecimento, essa constatação, foi crucial para sua consideração como maioria, o que Nelson Rodrigues viria a interpretar como a "revolução dos idiotas".

As obras de ficção, ao contrário do que nos impõe nossa vã ciência, são realidades tangíveis, são produtos culturais que se alimentam do princípio de fantasia, mas também visitam e esteiam-se no princípio de realidade. A confluência entre fantasia e realidade é 


\section{pro.posıções}

$e$-ISSN 1980-6248

http://dx.doi.org/10.1590/1980-6248-2016-0167

responsável pelo amálgama da formação subjetiva e pelo estatuto da vida material: crer também nos faz ser. Considerando tais acepções, não seria estranho recorrer às ideias de Marx para aprofundar a interpretação sobre o idiota, oferecida por Dostoiévski e por Nelson Rodrigues, no que diz respeito à ocupação de lugar de maioria.

A inversão da representatividade do idiota levou-o a ocupar indistintamente todos os setores da sociedade, independentemente de nível econômico, de classe social, de grau de instrução. Todas as instituições, quer no âmbito público ou privado, têm alta representatividade de idiotas. Essa ampliação se tornou interessante, como constataram Dostoiévski e Nelson Rodrigues, por conta da capacidade que tem o idiota de ater-se à efemeridade da mercadoria.

Por efemeridade da mercadoria pode-se conceber a fluida transição no valor de troca a que está submetida a mercadoria. Por conta disso, prontamente, quase tudo seria passível de intervenção, de trocas, na sociedade de capital. Relações sociais e amorosas, tais como aquelas rastreadas por Dostoiévski e por Nelson Rodrigues, mostram-se susceptíveis a transações valorativas e ideológicas por parte dos idiotas. Trata-se de sujeitos entusiasmados pelas novidades, pela transitoriedade, pela fluidez da mercadoria, de tal modo que, ao menor sinal de tédio, logo procuram estratégias de reanimação da alma. Essa fugacidade, na lógica do capital, não pode ser compreendida como sintoma. Constitui, na verdade, uma de suas essências, ao possibilitar que, ao menor sinal de estrangulamento do mercado, novos produtos e serviços possam ser oferecidos. Daí a atração quase que sensual exercida pela mercadoria. Uma sensualidade, nas palavras de Türcke (2014), sem sensações; ou melhor, uma sensualidade mais afeita ao evento sensacional do que às condições mais originais e imediatas de sensorialidade.

\section{Um complexo de ilusões: há luz no fim do túnel?}

Cônscios da massa de idiotas e da "sensacionalidade" dos eventos, os detentores do capital parecem ter as eficientes estratégias de soerguimento do mercado quando em via de declínio ou, em termos da economia política, de enfrentamento das quedas tendenciais das taxas de lucro. A palavra de ordem é a efemeridade da vida cotidiana, em que tudo, ou quase tudo, é passível de mercantilização. 


\section{pro.posıções}

$e$-ISSN 1980-6248

http://dx.doi.org/10.1590/1980-6248-2016-0167

O propósito, portanto, é criar um complexo de atrativos, de tal modo que mantenha os sujeitos em constante atividade, em uma suposta intervenção no real por meio do virtual. Utilizam-se da aparente potencialidade permitida pelas tecnologias ditas digitais, que ampliariam exponencialmente a capacidade de intervenção no mundo. De fato, como já constatava Lukács (2010) há mais de 40 anos, no mundo da informação e do mercado, tudo o que não se opõe aos interesses da manipulação é permitido!

Há luz no fim do túnel? Ou, melhor indagando: é possível, sob o imperativo da irracionalidade e destrutividade da lógica do valor de troca e do fetiche da virtualidade, a superação da condição de ser idiota?

Efetivamente, referida lógica representa uma inversão ou, mais precisamente dizendo, uma perversão do significado da existência genuinamente humana, fazendo com que a riqueza própria de cada sujeito, ou seja, seus atributos, suas capacidades naturais e as desenvolvidas na interação social, tenham seu valor determinado pelo mercado, em função de sua qualidade para produzir ou se tornar dinheiro - ressalte-se: duas faces da mesma condição de ser idiota, mesmo que não corresponda às reais necessidades do indivíduo e do gênero humano.

Os sujeitos passam a se encontrar com outros sujeitos não para efetivar sua vocação ontológica de ser mais, de humanizar-se, mas, ao contrário, como diria Marx (1993): “cada um tenta estabelecer um poder alheio sobre o outro, para com isso encontrar a satisfação da sua própria necessidade egoísta” (p. 210). A configuração das necessidades egoístas exacerbadas pelo capital, no bojo do processo de sua reprodução ampliada, aparece subjetivamente como posta pelos apetites humanos e não pela forma de organização social em curso, como se os homens possuíssem uma "essência egoísta”, a-histórica, justificando-se, assim, no capitalismo, o imperativo da barbárie: cada um por si, e o capital ou a mão invisível contra todos.

Presenciamos a evolução das subjetividades a uma processualidade aberrante de idiotização, na qual se nega o carecimento do outro, necessário, ontologicamente, à realização individual. $\mathrm{Na}$ base do capital, o encontro individualidade/generidade é cindido, independentemente da posição que o indivíduo ocupa na estrutura social - burguês ou trabalhador. Portanto, ambas as classes: a possuidora, que assume a aparência de não ser idiota, e a proletária, a aparentemente idiota, representam a mesma alienação humana. Ressalta Marx (1993), todavia, que a primeira, a classe proprietária, que assume a aparência do não ser 


\section{pro.posıções}

$e$-ISSN 1980-6248

http://dx.doi.org/10.1590/1980-6248-2016-0167

idiota, encontra-se confortável nessa alienação; sente nela uma confirmação, reconhece, nessa alienação de si, seu próprio poder e possui nela a aparência de uma existência humana; a segunda, a classe trabalhadora, a aparentemente idiota, sente-se destruída nessa alienação, vê nela sua impotência e a realidade de uma existência inumana.

Assim, é natural que a transformação dessa condição histórico-social de idiotas de ofício seja personificada nas figuras econômicas do capitalista ou do trabalhador e, consequentemente, a construção de uma nova forma de sociabilidade humana que seja de interesse da classe trabalhadora. Daí, contraditoriamente, a classe aparentemente idiota se constitui aquela capaz de conduzir o processo revolucionário que forjaria a superação da condição de ser idiota. As contradições em curso, no entanto, podem ser conduzidas tanto na direção da autoconsciência do gênero humano quanto na absorção da consciência pela faticidade fetichizada das relações sociais virtuais e efêmeras.

Faz-se aqui oportuno observar que, referindo-se às relações concretas certamente não lineares e não mecânicas entre os indivíduos e as determinações postas pela reprodução social, Lukács $(1978,2013)$ atesta, em consonância com Marx, a possibilidade de que contraforças e contratendências operem, nos limites postos pela reprodutividade capitalista, contra as desumanidades emanadas das prerrogativas do trabalho alienado. Assim é que, nesse sentido, reporta-se ao modo de agir de alguns indivíduos que se conservam na memória da humanidade (Luckács, 1978), por terem se colocado em condições de "dar um passo à frente em relação aos seus contemporâneos" (Lukács, 1978, p. 19). Se tais ações singulares são insuficientes para alterar - universalmente - as condições da generidade humana, para Lukács (1978), "nos momentos em que as possibilidades de uma adequação ao gênero para-si são materialmente exploráveis, contribuem para produzi-la efetivamente" (pp. 19-20).

Ao fim e ao cabo, a libertação das forças produtivas da sua determinação como capital constitui, portanto, o pressuposto da superação, de sujeitos efetivamente livres e universais da condição histórica do ser idiota. Nessa direção, em uma sociabilidade alicerçada sobre o trabalho social, o fazer-se indivíduo implicaria em tomar o outro indivíduo como sua maior riqueza. Os homens passariam, então, a se encontrar para efetivar sua vocação de ser mais, de humanizar-se. 


\section{pro.posıções \\ $e$-ISSN 1980-6248}

http://dx.doi.org/10.1590/1980-6248-2016-0167

Ainda que o modo de existência vigente tenha inaugurado um novo patamar, ou seja, um momento de inflexão importante no processo de humanização dos indivíduos, vivemos, paradoxalmente e contraditoriamente, sem sombra de dúvidas, na pré-história de sujeitos plenamente humanos.

\section{Considerações finais}

Parece evidente que um dos desafios à existência humana desde as circunstâncias de sociabilidade da cidadania grega até as diversas transições e representações da sociedade capitalista reside no enfrentamento da experiência individualidade-generidade. Talvez, por conta disso, a atração pelo conhecimento, pela sofia em sua vertente gnosiológica, mostrou-se como um demarcador de pertencimento à coletividade. Isso implicou elaboração de diversos meios de inclusão no domínio do social e, na mesma medida e velocidade, erigiu-se no meio de expurgos daqueles incapazes de pertencimento à comunidade da sobriedade.

No âmbito do pensamento, da ciência e da filosofia moderna, a localização ontológica do idiota pertenceu às cercanias quase exclusivas de sua "relação defeituosa" com a natureza, que, por sua vez, implicava em mal-estar social. E, a partir dessa racional reflexão, o instituto do asilamento se mostrou uma solução aparentemente viável para tais infelizes. Ressalte-se que, embora as massas possam ter sido asiladas, elas eram quase sempre vistas como minorias. Daí faz sentido a resistência humanitária, solidária e compreensível para avaliar a condição dessas "tais minorias", sobretudo no que diz respeito aos direitos humanos: isso tem sido a própria condição existencial dos estudos que se esteariam numa perspectiva pós-crítica.

Entretanto, é possível também admitir que a criticidade e a análise das contradições como motor das relações sociais sugerem a compreensão do ser social idiota a partir de outros patamares, a partir da perspicácia sensível encontrada em Marx, Lukács, Freud, Dostoiévski, Nelson Rodrigues e tantos outros; e conduzem a diferentes linhas de reflexão, amparadas na "velha" e tão atual criticidade.

E, a partir dessa compreensão, seria possível admitir que os idiotas não seriam minorias, muito menos detentores de incapacidades que os poriam em condição de desvantagem diante da tão litigiosa relação individualidade-generidade. O que aparentemente se apresentaria, conforme algumas reflexões críticas elaboradas nos tópicos aqui expostos, é 


\section{pro.posıções}

$e$-ISSN 1980-6248

http://dx.doi.org/10.1590/1980-6248-2016-0167

que a atual condição de sociabilidade estaria marcada por massificação esmagadora de idiotas, condição ontológica essa que teria representantes nas mais diversas classes sociais e intelectuais, nos mais diversos segmentos da sociedade e que, embora haja sobressaltos, aclaramentos de suas próprias condições existenciais de idiotas, esses espasmos ainda não se tornaram suficientemente fortes para forjar uma sociedade de indivíduos livres e universais e, portanto, não idiotas.

\section{Referências}

Adorno, T. (1994). O ensaio como forma. In G. Cohn (Org.), Theodor W. Adorno: sociologia (pp. 167-187). São Paulo: Ática.

Adorno, T. (1995). Educação após Auschwitz. In T. Adorno, Educação e emancipação (pp. 119154). Rio de Janeiro: Paz e Terra.

Almeida, L. S. (1988). Teorias da inteligência. Porto: Edições Jornal de Psicologia.

Bárcena, F. (2015, janeiro/abril). La diferencia (de los idiotas). Pro-Posições, 26(1), 49-67. Retirado em 11 de maio de 2016, de

$<$ http://www.scielo.br/scielo.php?script=sci_arttext\&pid=S0103-

$73072015000100049 \& \operatorname{lng}=\mathrm{es} \& n r m=\mathrm{iso} \& \ln \mathrm{ln}=\mathrm{en}>$.

Chaves, H. V., \& Maia Filho, O. N. (2016, janeiro/março). Percepção de tempo e necessidade de atividade na sociedade do excesso: educação no contexto das tecnologias digitais. ETD - Educação Temática Digital, 18(1), 71-82. Retirado em 22 de fevereiro de 2016, de <http://periodicos.sbu.unicamp.br/ojs/index.php/etd/article/view/8635719/12228.

Chun, J. M. (2009). A nation of a bundred million idiots? A social bistory of Japanese television. New York: Routledge.

Dostoiévski, F. (2008). O idiota. São Paulo: Editora 34.

Foucault, M. (2014). História da loucura na idade clássica. São Paulo: Perspectiva.

Garcia-Roza, L. A. (2005). Freud e o inconsciente. Rio de Janeiro: Jorge Zahar. 


\section{pro.posıções \\ $e$-ISSN 1980-6248}

http://dx.doi.org/10.1590/1980-6248-2016-0167

Lukács, G. (1978). As bases ontológicas do pensamento e da atividade do homem. Revista Temas de Ciências Humanas, n.v.4, 1-20.

Lukács, G. (2010). Prolegômenos para uma ontologia do ser social. SP: Boitempo.

Lukács, G. (2013). Para uma ontologia do ser social II. SP: Boitempo.

Marx, K. (1985). A miséria da Filosofia. São Paulo: Global.

Marx, K. (1989). O capital. Rio de Janeiro: Bertrand Brasil.

Marx, K. (1993). Manuscritos econômico-filosóficos. Lisboa: Edições 70.

Meszáros, I. (2009). A teoria da alienação em Marx. São Paulo: Boitempo.

Postman, N. (1994). Tecnopólio: a rendição da cultura à tecnologia. São Paulo: Nobel.

Rodrigues, N. (1993). O óbvio ululante: primeiras confissões. São Paulo: Companhia das Letras.

Türcke, C. (2014). Sociedade excitada: filosofia da sensação. Campinas, SP: Editora da Unicamp.

Van Drenth, A. (2007, fevereiro). Mental boundaries and medico-pedagogical selection: Girls and boys in the Dutch 'School for Idiots', The Hague 1857-1873. Paedagogica Historica, 43(1), 99-117. Retirado em 11 de maio de 2016, de $<$ http://eric.ed.gov/?id=EJ763864>.

Wallon, H. (2008). Do ato ao pensamento. Petrópolis, RJ: Vozes.

Zenderland, L. (1998). Measuring minds: Henry Herbert Goddard and the origins of American intelligence testing. Cambridge: Cambridge University Press.

Submetido à avaliação em 28 de novembro de 2016; aceito para publicação em 02 de fevereiro de 2017. 